\author{
JANUARY 2017, VOLUME 5, ISSUE 1, 51 - 61 \\ E-ISSN NO: $2289-4489$
}

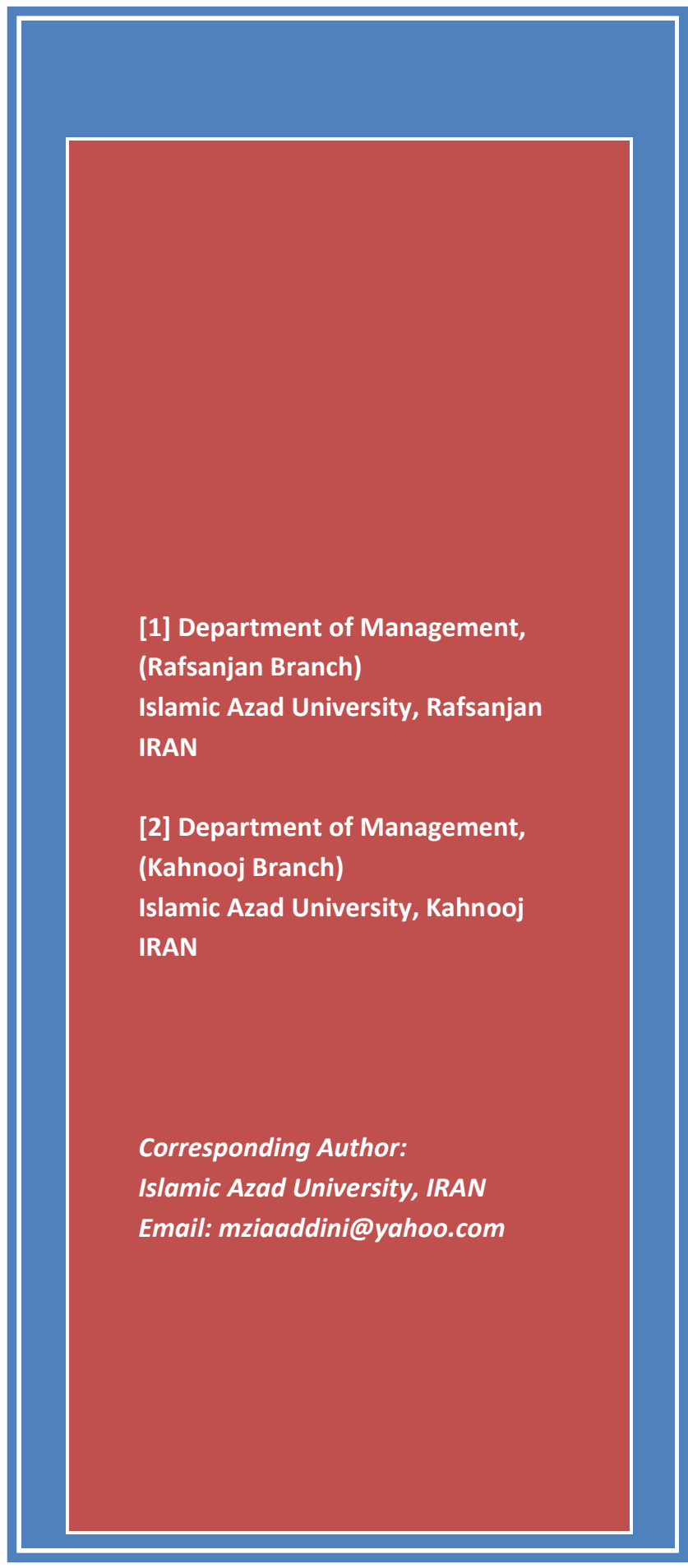

\title{
INFLUENCE OF PARTICIPATIVE MANAGEMENT AND PERCEIVED ORGANIZATIONAL JUSTICE ON UNIVERSITY WORK CULTURE \\ Mohammad Ziyaaddini ${ }^{1} \&$ Mohammad Yari Naserieh ${ }^{2}$ (PhD)
}

\begin{abstract}
The current study used Structural Equation modeling to investigate the relationship between participative management with work culture through the mediator variable of perceived organizational justice. The statistical population included all employees (190 academic staff) at universities of Rafsanjan (Iran) in 2014-2015. Based on the Krejcie and Morgan Tables, 126 subjects were selected as the sample through random class method. In order to collect data, we employed three sets of questionnaires (perceived organizational justice, participative management and work culture) that have a proper validity and reliability. Partial Least Squares method was used to analyze data. Structural Equations Method is adopted in order to test the research hypotheses. The results of research show that perceived organizational justice can mediate the relationship between participative management and work culture in universities.
\end{abstract}

Keywords: perceived organizational justice, participative management, work culture, university, Iran 


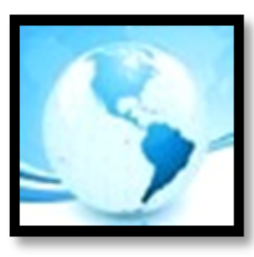

\section{MALAYSIAN ONLINE JOURNAL OF EDUCATIONAL MANAGEMENT (MOJEM)}

\section{INTRODUCTION}

Work culture as life method has a basic and substructure role in promoting dynamic level of societies. Comparing with some concepts such as organizational culture, general culture and other meanings work culture has been less defined. Providing conditions to make decisions based on wisdom and policy in all stages of life especially in childhood is regarded as the main and effective base on creating and reinforcing work culture. Studies of Iran social problems experts show that work culture in Iran is at lower level than in developed communities. In addition, several political and social authorities and leaders of Iran emphasize on this subject by their messages and lectures. Results of the seminar on "work culture evolution" in 1996 have been published as a set of papers by the work administration and social affairs center which show that based on ideas of many economic experts, work morale and culture is weak in Iran; however, it is necessary to consider lack of proper work morale and culture as an economic and social problem. And some studies performed by economic thinkers and authorities are used to recognize current conditions well from viewpoint of work culture and morale in addition to related factors. In this regard, strategic role of human force and its attitudes to work and providing meaning of work culture in the world are very important. While instituting work culture, work is considered as a value and all employees and workers work to develop society in balance and help to develop the economy by good work. In general, to get a powerful organizational culture it is necessary to increase employees' mental connection and commitment to organizational values and goals.

Organizational commitment can be defined as one's mental connect to the organization involving in job and believing organizational values are felt. Work culture can be classified into two mental and behavioral dimensions: mental dimension of work culture shows general meaning of work and includes work meaning and value in one's point of view; but the behavioral dimension looks at one's work commitment rate (Akbari \& Ardashiri, 2002).

Participative management means employee involvement in the decision making process, inviting everyone to accept individual responsibility to increase service and product quality and rewarding employees' behavior which in their views satisfies customers and improve organization function over time (Davis, 2001).

Participation is a mental and emotional involvement of people in group positions which motivates them to help meet group objectives and participate in work responsibility (Toussi, 2000). Also, organizational justice is a phrase used to describe the role of justice which relates to job position directly. Especially in organizational justice it is mentioned how employees should behave fairly (Abaspur, 2009).

Justice and fair processes are regarded as perspectives in organizational life which emerge often in the frame of employees' discussion about receiving or not receiving suitable results (distributional justice) and whether managers' decision process in order to get these results is correct or not (procedural justice). In addition, plan of political justice and third dimension known as interactional justice emerge too. In this form of organizational justice interpersonal actions and measures of organization, especially manner of relation and reaction between managers and directors with employees are emphasized (Nadi, Moshfeqi, \& Siadat, 2009). Meanwhile, regarding fast changes for which delaying to answer may be very expensive and problematic, if thinking can be changed, practically these changes can be reacted fast and properly. Employee participation in management empowers the organization to agree to these changes. Employees and customers' cooperation with management and improving organization is performable by presenting a suggestion system. A successful and healthy culture of cooperation results in the highest satisfaction level of employees, customer loyalty and organizational efficiency.

These research variables have been studied in recent years, but effects of these factors need to be studied more and it is necessary to regard them increasingly; because no sample is available which evaluate all variables at the same time. This research tries to fill the related gap and study effective variables on work culture in the frame of a single model. Main problem of the research is whether participative management can be regarded independently 


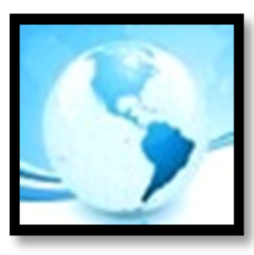

for its effect power apart from other effective factors with work culture on variables of perceived organizational justice. Therefore, the objectives of the study are:

a. To analyze the participative management effects on work culture.

b. To analyze the participative management effects on work culture with perceived organizational justice as the mediator variable.

\section{THEORETICAL FOUNDATIONS OF RESEARCH}

Masterson (2001) in a research shows that distributional and political justice relate to commitment. In his view if employees feel more about presence of justice in distributing rewards and decisions policies, they will show more commitment to their behavior and attitude. Using 178 teachers he showed that when teachers in an institute feel presence of distributional and political justice in their institute more, they will show more commitment in their behavior and attitude. It is worth noting that students and teachers who feel high presence of distributional and political justice in their institutes explain more positive factors to their teachers. This researcher mentions that justice perceptions can affect organizational and individual results.

Klenduer and Deller (2009) who researched organizational justice and management commitment in integrating firms concluded that if dimensions of fairness relate to effective commitments, just organizational justice has a unique relationship with it. Results show that instrumental evaluation and trust can serve as a justifier variable. They also explain that every dimension of justice relates to effective commitments positively and significantly. If people feel that there are no unfair decision policies in distributing rewards and there is no discrimination in interactions between people, they will reinforce themselves to be committed to the organization and these reinforce the serving spirit and work conscience in people. Results of Shafeepour Motlaq (1998) show that motivational factors and correct human relationships are effective in developing work conscience. Apparently, if employees observe no discrimination in the organization, they are motivated to perform best and it seems that improving relationship between people especially between directors and subordinates increases work conscience. Sarookhani and Talebian (2002) also show that there is a positive and significant correlation between work conscience level and positive feeling of justice in the organization; it seems that increasing positive feeling of people to justice present in organization increases their work conscience.

Ghafoori and Golparvar (2008) studied the relationship between organizational justice and employee organizational commitment in central municipalities of Isfahan city. Results show that organizational justice and its three components correlate with every area of organizational commitment containing emotional organizational commitment, normative organizational commitment and constant organizational commitment positively and significantly. Results of multiple regression analysis show a multiple significant correlation between three kinds of organizational justice including distributional justice, political justice and interactional justice with organizational commitment. Behravan and Saeedi (2009) found that organizational commitment relates to variables of organizational justice, independency in work, role pressure, job opportunity and promotion in addition to role ambiguity positively and significantly and does not relate to organizational partnership significantly. Multiple regression analysis and results of method analysis show that organizational justice is regarded as the most important and determinant factor affecting organizational commitment directly and positively. While other factors of organizational partnership, role ambiguity, role pressure and work independency affect organizational commitment directly; and opportunity factor in addition to job promotion affect it indirectly.

Etebarian and Ahmadipanah Mehrabadi (2011) analyzed the relationship between perceived organizational justices with employees' work conscience in Khorasgan Islamic Azad University. Results show a positive and direct relationship between perceived organizational justice and its dimensions (distributional justice, political justice and 


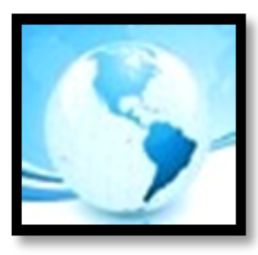

\section{MALAYSIAN ONLINE JOURNAL OF EDUCATIONAL MANAGEMENT (MOJEM)}

relational justice) with work conscience. Among some variables such as sex, service years, education level, employment and work environment, only education level affects relationship between perceived organizational justice and work conscience. No significant difference resulted between justice components (distributional, political and relational) based on sex, service years, education level, employment and work environment. Chalbi (2006) in a research studying work morale among employees in governmental, non-profit, private and cooperative organizations in Tehran, Kermanshah and Yazd(Iran) cities showed that increasing work general commitment in social macro-level depends on national identity reinforcement in cultural level, relates to positive views of work and emphasizing on work internal values in cultural macro-level depends on reinforcing minimum work norms and standards and finally relates to job satisfaction in personal level. Moeedfar (2004) showed that increasing cooperative management raises employees work morale in governmental section. Studying work conscience and effective social factors in Iran national petrochemical industries Sarookhani and Talebian (2002) show that developing organizational justice, expert fitness with job tasks, developing intra-organizational satisfaction, instituting cooperative methods and also distributing jobs based on employee abilities and desires have a positive relationship with job conscience and they can explain more than $50 \%$ of job conscience variance. Jaafari and Habibi (2003) compared work culture in two manufacturing and industrial companies. Results of the research show that the weakest degrees in both organizations relate to organizational justice and these variables affect work culture negatively. In addition, low work ability caused decreased work culture and feeling of job satisfaction caused increase in work culture. In a research as "work moral and effective social factors on it in Tehran manufacturingindustrial workshops" Moeedfar (2004) showed that work morale in a relatively high level, but work morale level of educated people and burgesses is less than uneducated people and rural people. The proposed hypotheses for this study are formulated as follows:

H1: Participative management affects work culture.

$\mathrm{H}$ 2: Participative management affects work culture with perceived organizational justice as the mediator variable.

\section{METHODOLOGY}

\section{Research Design and Instrumentation}

To measure research construction three questionnaires of perceived organizational justice, Participative management and work culture were used. The questionnaire has been adapted from previous studies and modified to fit the current context. From Table1 Part A consists of items related to distributed Participative management ( 8 questions adapted from Ahmadi (2012)). Part B consists of items related to distributed Perceived Organizational justice (18 questions adapted from Abaspur (2009). Part C measures work culture (8 questions adapted from Ahmadi (2012) that have a proper validity and reliability). The questionnaire was scored on a 4-point modified Likert scale of Strongly Agree (SA), Agree (A), Strongly Disagree (SD), and Disagree (D) with weights 4, 3, 2 and 1 respectively.

The data were analyzed using the Statistical Packages for the Social Sciences (SPSS) version 21.0 and Structural Equation Modelling (SEM) using partial least square (PLS) version 3 software. The Structural Equation Model of the study is shown in Figure 1. It depicts distributed cooperative management factor as the exogenous variable and work culture as the endogenous variable while the perceived organizational justice is the mediating variable. 


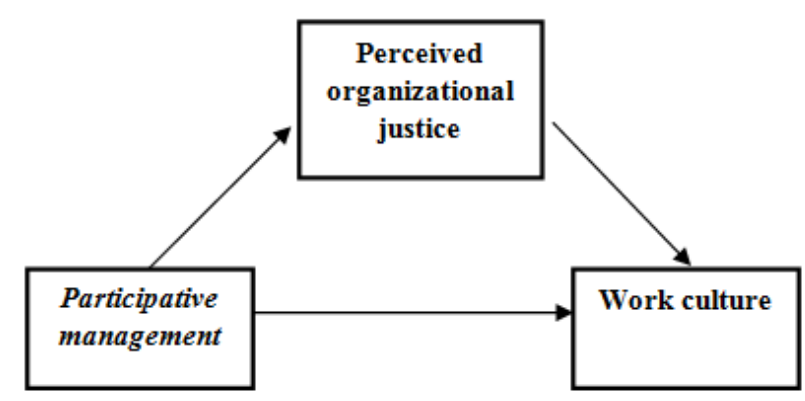

Figure 1. Conceptual Framework of the Study (Source:Ahmadi,2012)

\section{Research Sample and Location}

Population included all employees (190 Academic staff) at universities of Rafsanjan (Iran) in 2014-2015. Based on the Krejcie and Morgan Tables, 126 subjects were selected as the sample through random class method.

\section{Data Collection Procedures}

This study used primary data collected through questionnaires. First, respondents were assured that all their responses in this study will be kept confidential. The study emphasizes on 'close ended' questionnaires which are answered based on the Likert scale (four point scales) to determine the level of interest and perception of each element available. All questionnaire items were analyzed using the Statistical Packages for the Social Sciences (SPSS) version 21.0 and Structural Equation Modelling (SEM) using partial least square (PLS) version 3 software in order to obtain descriptive statistics data. Partial least square method (PLS) is formed of two parts (Davari \& Rezazadeh, 2013). In the first part the measurement sample is studied that is Internal Reliability and validity of research variables and instruments. Composite Reliability (CR) is a better scale to model structural equation than Cronbach alpha; because in calculating Cronbach alpha about every variable, all parameters enter in calculation by the same importance.

While to calculate CR a parameter with more factorial load is more important. This subject makes CR rates of variable more reliable and exact than Cronbach alpha. CR rate for every variable more than 0.7 and less than 0.6 shows lack of reliability. Next scale to study fitness of measurement model is convergent validity which studies the correlation rate of every variable with its questions (parameters). In this area the Average Variance Extracted (AVE) scale is used. AVE rate for every variable is more than 0.4 (Davari \& Rezazadeh, 2013).

\section{FINDINGS}

In Table 1, factorial loads, composite reliability and convergent validity of every variable are presented. In this table parameters with 0.7 factorial loads such as parameter 3 of Work culture variable are omitted from analysis; because they have no significant load for other variables. Regarding bases mentioned in text, rates of this table show enough credit of variables. 
Table1

Studying credit of research variables

\begin{tabular}{|c|c|c|c|c|c|}
\hline & Factorial load & parameter & Factorial load & $\begin{array}{l}\text { Factorial } \\
\text { load }\end{array}$ & parameter \\
\hline 0.506 & $\begin{array}{l}\text { Participative } \\
\text { management } 1\end{array}$ & 0.557 & Organizational justice 1 & .639 & Work Culture 1 \\
\hline 0.811 & $\begin{array}{l}\text { Participative } \\
\text { management } 2\end{array}$ & 0.642 & Organizational justice 2 & .709 & Work Culture 2 \\
\hline 0.867 & $\begin{array}{l}\text { Participative } \\
\text { management } 3\end{array}$ & 0.646 & Organizational justice 3 & .344 & Work Culture 3 \\
\hline 0.716 & $\begin{array}{l}\text { Participative } \\
\text { management } 4\end{array}$ & 0.613 & Organizational justice 4 & .647 & Work Culture 4 \\
\hline 0.789 & $\begin{array}{l}\text { Participative } \\
\text { management } 5\end{array}$ & 0.669 & Organizational justice 5 & .651 & Work Culture 5 \\
\hline 0.516 & Cooperation 6 & 0.711 & Organizational justice6 & .662 & Work Culture 6 \\
\hline 0.750 & $\begin{array}{l}\text { Participative } \\
\text { management } 7\end{array}$ & 0.692 & Organizational justice 7 & .642 & Work Culture 7 \\
\hline \multirow[t]{11}{*}{0.648} & $\begin{array}{l}\text { Participative } \\
\text { management } 8\end{array}$ & 0.662 & Organizational justice 8 & .738 & Work Culture 8 \\
\hline & & 0.640 & Organizational justice 9 & & \\
\hline & & 0.750 & Organizational justice 10 & & \\
\hline & & 0.715 & Organizational justice 11 & & \\
\hline & & 0.571 & Organizational justice 12 & & \\
\hline & & 0.681 & Organizational justice 13 & & \\
\hline & & 0.744 & Organizational justice 14 & & \\
\hline & & 0.653 & Organizational justice 15 & & \\
\hline & & 0.738 & Organizational justice 16 & & \\
\hline & & 0.728 & Organizational justice 17 & & \\
\hline & & 0.637 & Organizational justice 18 & & \\
\hline 0.712 & & .938 & & .843 & Composite Reliability \\
\hline 0.512 & & .457 & & .454 & convergent validity \\
\hline
\end{tabular}

Other important measure determined by divergent validity is the relationship between variables with their parameters comparing with their relationship with other variables; as accepted divergent validity of a model explains that a variable in model has more interaction with its parameters than other variables. Divergent validity is assessed by comparing correlation rate of a structure with its parameters against correlation of that variable with other variables; the Fornell and Larcker (1981) is used in which AVE square of one variable should be more than the correlation of that variable with other variables (Davari \& Rezazadeh, 2013).

As determined in Table 2, AVE square rate of variables in present blocks are located in main diameter that is more than correlation rate among them which are located in below blocks in right of main diameter. However, it can be explained that in current research, variables in model have more interaction with their parameters than other variable. In other words, model discriminant validity is suitable. Also, regarding the correlation matrix, among variables the highest correlation rate relates to relationship between perceived organizational justice and participative management. 


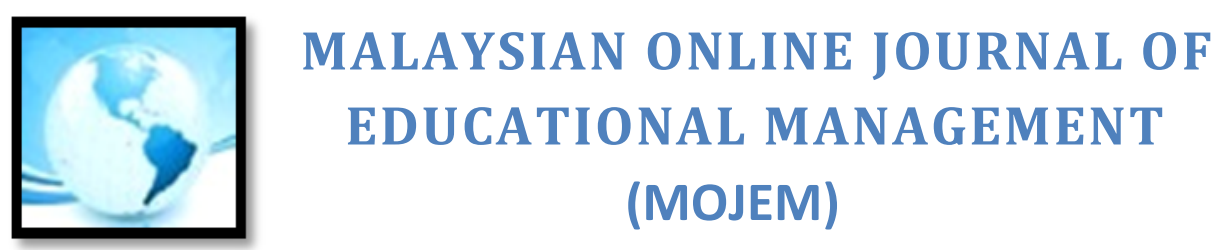

Table2

Correlation Matrix and Discriminant Validity of Research Variables

\begin{tabular}{|c|c|c|c|c|}
\hline $\begin{array}{l}\text { Participative } \\
\text { Management }\end{array}$ & $\begin{array}{l}\text { Work } \\
\text { culture }\end{array}$ & $\begin{array}{l}\text { Perceived } \\
\text { justice }\end{array}$ & Organizational & Variables \\
\hline & & .676 & & Organizational Justice \\
\hline & .673 & .128 & & Work culture \\
\hline .715 & .412 & .666 & & Participative management \\
\hline
\end{tabular}

Structural sample test: structural sample PLS and research hypotheses were used by studying Beta coefficient and Boot Strapping method to calculate $Z$ statistics rate in order to determine route coefficients significance. Route coefficients are used to determine share of every independent variable to explain dependent variables variance (Table 4).

And rate of $R^{2}$ shows explained variance of dependent variable by independent variables. It indicates effect of an exogenous variable on an endogenous variable and three rates of $0.19,0.33$ and 0.67 are regarded as base rate for weak, medium and strong rates of $R^{2}$. According to the Table $3, R^{2}$ rate for work culture is calculated equal to 0.219 and for perceived organizational justice equal to 0.447 that is in relatively medium level for work culture and perceived organizational justice.

Table 3

$R^{2}$ rate for Work Cultur perceived Organizational Justice and culture

\begin{tabular}{lll}
\hline perceived organizational justice & Work culture & variable \\
\hline 0.447 & 0.219 & $R$ Square \\
\hline
\end{tabular}

$\mathrm{H}_{1}$ : Participative management effects on work culture.

As shown in Table 4 and Figure 2, significant coefficient of route between Participative management and work culture is 3.607 (according to 5\% error principle in rejecting hypothesis 0 for rates of 1.96 and -1.96 per model parameters) that is estimated more than 1.96. So, it can be explained that researcher's objective is approved with 95\% confidence. Regarding positivity of route coefficient, it can be said that Participative management affects work culture positively and significantly.

Table 4

Route Coefficients, Z Statistics

\begin{tabular}{llll}
\hline $\begin{array}{l}\text { Significance } \\
\text { level }\end{array}$ & Z statistics & $\begin{array}{c}\text { Effect } \\
\text { coefficient }\end{array}$ & Route \\
\hline $\mathrm{P}<0.05 \mathrm{pp}$ & 13.661 & 0.669 & $\begin{array}{l}\text { Participative management } \rightarrow \text { Perceived organizational } \\
\text { justice }\end{array}$ \\
$\mathrm{P}<0.1$ & 1.859 & 0.293 & $\begin{array}{l}\text { Perceived organizational justice } \rightarrow \text { Work culture } \\
\mathrm{P}<0.05\end{array}$ \\
\hline
\end{tabular}


$\mathrm{H}_{2}$ : Participative management effects on work culture with perceived organizational justice as the mediator variable.

As shown in Table 4 and Figure 2, significant coefficient of route between Participative management and perceived organizational justice is 13.661 (according to 5\% error principle in rejecting (hypothesis 0 ) for rates of 1.96 and 1.96 per model parameters) that is estimated more than 1.96 . So, it can be explained that the researcher's objective is approved with $95 \%$ confidence. Regarding positivity of route coefficient (0.669) it can be said that Participative management affects perceived organizational justice positively and significantly. Also significant coefficient of route between perceived organizational justice and work culture is 1.859 (according to $10 \%$ error principle in rejecting (hypothesis 0) for rates of 1.64 and -1.64 per model parameters) that is estimated more than 1.64. So, it can be explained that the researcher's objective is approved with $90 \%$ confidence.

Regarding positivity of route coefficient $(0.293)$ it can be said that perceived organizational justice affects work culture positively and significantly. So it can be said that Participative management affects on work culture with perceived organizational justice as the mediator variable.

To determine the effect of mediator variable of perceived organizational justice in relationship between Participative management and work culture and in order to determine indirect effect of mediator variable VAF1 statistics is used which selects between 0 \& 1 and approaching it to 1 shows more strong effect of mediator variable.

(Equation 1)

$$
=\frac{a \times b}{V A F}
$$

a) Coefficient rate of route between independent and mediator variables

b) Coefficient rate of route between dependent and mediator variables

c) Coefficient rate of route between independent and dependent variables

$$
\frac{0.669 \times 0.293}{(0.609 \times 0.293)+0.611}=0.24
$$

It means that $24 \%$ of total effect of Participative management on work culture is explained indirectly by the mediator variable of perceived organizational justice.

\section{CONCLUSION AND DISCUSSION}

Results of the research show that cooperative management affects work culture directly and increasing Participative management raises work culture. Findings by Sarookhani and Talebian (2002) show that instituting cooperative methods relates to work conscience positively and they can explain more than $50 \%$ of variance rate of work conscience.

Moeedfar's research (2004) shows that increasing cooperative management raises work moral of governmental employees and it is supported by Ahmadi (2012) in which it is indicated that cooperative management can explain changes. Results show that cooperative management affects perceived organizational justice; and increasing cooperative management increases organizational justice. 


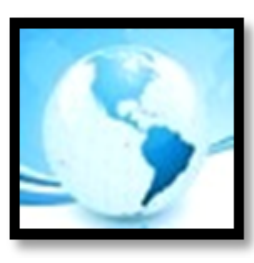

\section{MALAYSIAN ONLINE JOURNAL OF EDUCATIONAL MANAGEMENT (MOJEM)}

In this regard no study is found to compare with. Results of this research show that perceived organizational justice affects work culture directly and increasing organizational justice raises work culture. Findings by Jaafari and Habibi (2003) show that organizational justice affects work culture negatively.

In addition, findings of Sarookhani and Talebian (2002) show that developing organizational justice correlates with work conscience positively. Iman and Arjmand nia 's research (2007) that decreasing organizational justice increases organizational estrangement. In addition, Chalbi's research (2006) shows that increasing organizational justice promotes work morale. Ahmadi (2012) in his research explains that there is a significant relationship between organizational justice and its dimensions with work culture and its dimension. Masterson (2001) explained that distributional and political justice relate to commitment. In a research conducted by Klendauer and Deller (2009), it is shown that every dimension of justice relates to effective commitments positively; if people feel that there is no discrimination between distributing rewards, decisions methods and interaction among people in the organization, they make themselves committed to the organization.

Shafeepour Motlaq's (1998) research shows that if no discrimination is observed by employees in an organization, they will be motivated to work in the best possible way. In addition, it seems that improving employees' relationships especially relationship between directors and subordinates increases work conscience. Ghafoori and Golparvar's research (2008) shows that regression analysis of three kinds of organizational justice including distributional, political and interactional justice has a multiple significant correlation with organizational commitment. Research by Behravan and Saeedi (2009) shows that organizational justice is the most important and determinant factor which affects organizational commitment directly and positively.

Research by Etebarian and Ahmadipanah Mehrabadi (2011)shows that there is a positive and significant correlation between organizational justice and its dimensions with work conscience. By approving two effective routes on cooperative management on organizational justice and effective route of organizational justice on work culture, the mediator role of organizational justice is approved in relationship between cooperative management and work culture. Therefore, approving mediator role of organizational justice can explain that cooperative management can affect work culture indirectly by organizational justice and its indirect effect is equal to 0.24 .

\section{RECOMMENDATIONS}

Regarding perceived organizational justice effect on work culture, to improve work culture organizations should try to explain organizational justice by setting fair reward and punishment system in universities and indicate main reasons for making decisions about resource allocation clearly and truly; authorities of making decisions respect people who are influenced by decisions and all verbal and non-verbal communications should be based on loyalty; equal regulations should be generalized for all employees and the feeling should be reinforced that the organization behaves fairly toward them.

Considering that participative management affects work culture and perceived organizational justice, the findings suggest creating a more participative management system whereby managers and authorities respect employees and subordinates' ideas to make decisions. Finally, universities can reinforce participative management by organizational justice to improve work culture. One limitation of this research is that self-report questionnaires were used to measure research variables and it is possible that the answers to these questions are influenced by participants' motives, education level and social desirability orientation. Also, design of current research is structural equations sampling which cannot prove causality and it should be considered. 


\section{REFERENCES}

Abaspur, M. (2009). The relationship between perceived organizational justice with Ethical Behaviors in executive organizations in Kerman. (Unpublished M.S thesis, Islamic Azad University, Branch of Rafsanjan).

Ahmadi, S. (2012). Studying work culture and effective social factors on it. Application Sociology, 2( 46) 21-40. [in Persian].

Behravan, H., \& Saeedi, R. (2009). Effective factors on employees' organizational commitment in Khorasan Razavi Gas Company. Social Science Quarterly in Mashhed Ferdosi University, 2,181-199. [In Persian].

Akbari, K., \& Ardashir, M.( 2002), Effective factors on work culture. Social Science Quarterly in Shahid Beheshti University, 35,181-209. [In Persian].

Chalbi, M. (2006).Work commitment. A set of social analysis papers in action space. Tehran, Iran: Nashr ney.

Davari, A., \& Rezazadeh, A. (2013). Modelling structural equations by PLS software. Tehran, Iran: Jehad Daneshgahi.

Etebarian, A., \& Ahmadipanah Mehrabadi, A. (2011). Relationship between perceived organizational justice and employees' job conscience in Kharsgan Islamic Azad University. Educational Management and leadership quarterly of Garmsar Islamic Azad University, 5(2), 23-41. [In Persian].

Fornell, C., \& Larcker, D. F. (1981). Evaluating structural equations models with unobservable variables and measurement Error. J Market Re,18 (1), 39-50

Ghafouri, M.,\& Golparvar, M. (2008). The relationship between perceived organizational justices with organizational commitment, Psychological Studies, 4(2), 129-148. [In Persian].

Imani, M., \& Arjmand nia, A. (2007). Relationship between organizational justice and job satisfaction among male and female teachers of schools. Social Psychological Researches Quarterly, 5(2). [In Persian].

Jaafari, M., \& Habibi, M. (2003). Work culture, Tadbir Monthly,-125, 70-73. [In Persian].

Klendauer, R., \& Deller, J. (2009). Organizational justice and managerial commitment in corporate mergers. Journal of Managerial Psychology, 24(1), 29-45.

Krejcie, R. V., \& Morgan, D. W. (1970). Determining Sample Size for Research Activities, Educational and Psychological Measurement, 30, 607-610.

Masterson, S. (2001). A trickle-down model of organizational justice: Relating employees' and customers' perceptions of and reactions to fairness. Journal of Applied Psychology, 86(4), 594-604.

Moeedfar, S. (2004). Studying work moral and individual and social factors affecting on it among employees employed in Tehran governmental offices. Tehran, Iran. 


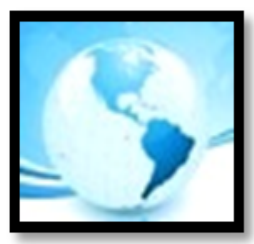

Nadi, M., \& Moshfeqi, N., \& Siadat, A. (2009). Relationship between teachers' trust to managers and organization with their perception of distributional, political and interactional justice in Isfahan City. Education and Research Magazine, 24, 25-42. [In Persian].

Sarookhani, B., \&Talebian, A. (2002).Work conscience and effective factors on it. A research in Iran national petrochemical industry. Iran Sociology, 4, 162-188. [In Persian].

Shafeepour Motlaq, F. (1998).Studying role of correct measurement method on employees' work conscience. (Unpublished M.S thesis, Islamic Azad University, Branch of Kharsgan).

Davis, T. R. V. (2001). Integrating internal marketing with participative management. Management Decision, 39(2), 121-132.

Toussi, M. (2000). Cooperative management and improving organization instructions. Tehran, Iran: Governmental Management Training Center. 